\title{
O Board Brasileiro de Ortodontia
}

Muito já foi escrito sobre a qualidade do tratamento ortodôntico e talvez mais ainda sobre a estabilidade dele. Entretanto, não há tantos trabalhos sobre a associação entre esses dois fatores: excelência e estabilidade. E mais ainda, há um nível de corte na qualidade do tratamento a partir do qual ele tende a ficar mais estável?

Recentemente, ministrei uma palestra na Conferência Britânica de Ortodontia e um apresentador que me sucedeu discorreu sobre um trabalho que publicara ${ }^{1}$ e do qual tinha sido orientador. Casos, ao serem finalizados e após anos sem contenção, foram analisados segundo os critérios de pontos do Board Americano de Ortodontia. A seguir, esses dois tempos foram comparados. Os resultados demonstraram que os casos melhor tratados tenderam a piorar, enquanto outros, que não seriam aprovados no exame ao final do tratamento, tendiam a melhorar - por vezes o suficiente para passar no exame, após decorridos alguns anos do fim do tratamento. As conclusões do estudo foram que uma acomodação ocorre depois de algum tempo do término do tratamento, e que atingir uma oclusão perfeita não assegura estabilidade em longo prazo.

Estando cientes desse achado, duas perguntas naturais podem ser formuladas. Precisamos da excelência clínica na finalização dos tratamentos? Por que devemos nos submeter à estressante prova de um Board? As respostas são, respectivamente, sim e há várias razões para isso. Vejamos os porquês.

Inicialmente, as entrelinhas do artigo de Netta e Huang mostram que os casos melhores, mesmo piorando, permaneceram os melhores. Ou seja, os níveis de desvios do ideal continuaram a ser menores que os daqueles casos concluídos com mais imperfeições. Isso significa que um caso bem terminado continuará bem, mesmo que uma leve piora ocorra com o tempo, e isso não deve frustrar nem o ortodontista nem o paciente, pois não há qualquer procedimento clínico feito no corpo humano que perdure para sempre.

Adicionalmente, pacientes nos procuram para tratamentos relativamente longos e desejam - quase sempre a excelência. Essa é a que provê os fantásticos resultados estéticos e funcionais que a Odontologia moderna pode proporcionar e que muitas pessoas da sociedade sonham em possuir. As pessoas desejam a excelência em seus sorrisos porque querem, cada vez mais, se sentir bonitas, saudáveis e atraentes, independentemente da idade. Por vezes, isso faz parte apenas do amor-próprio; por outras, das necessidades sociais ou profissionais. Não importa. O objetivo é um só.

A segunda pergunta trata das justificativas de nós, profissionais, nos submetermos a uma prova que analisa nossa qualidade profissional; e mais, fazermos isso de forma espontânea. Existem razões, e são muitas; entretanto, começarei a explicação por um leve prefácio do estágio de desenvolvimento dessa prova em nosso país.

No Brasil há uma entidade equiparável à existente nos EUA, que é o Board de Ortodontia e Ortopedia Facial (BBO), fundado em 2002. O BBO é uma entidade que oferece um programa de certificação para ortodontistas que estão preocupados com a excelência de seu trabalho e que queiram se submeter a exames de qualificação. Os aprovados recebem o título de "Diplomado pelo Board Brasileiro de Ortodontia e Ortopedia Facial". Ele é o primeiro e, até o presente momento, o único Board de Excelência existente entre as especialidades da Saúde no país. O certificado emitido pelo Board não equivale a um título profissional ou acadêmico, nem confere qualificação, privilégio ou licença para a prática da Ortodontia. Trata-se de um certificado de mérito clínico que permite a avaliação dos conhecimentos do profissional.

Há alguns motivos para realizarmos a prova. No Brasil, assim como em qualquer lugar do mundo, existem cursos de pós-graduação e profissionais de diferentes expertises. Talvez essa discrepância tenha especial relevo em nosso país devido à falta de uma política eficaz que prime pelo fortalecimento da educação superior na área da Saúde. A certificação do BBO dá ao profissional a capacidade de, documentadamente, mostrar à sociedade sua capacitação e sua busca pelo aperfeiçoamento. *

Paralelamente, podemos inferir sobre a qualidade de certos cursos de pós-graduação capazes de produzir, consistentemente, profissionais exitosos no exame.

Esses dois fatores, em conjunto, formam uma verdadeira espiral positiva que tende a melhorar a qualidade de nossas pós-graduações e, por conseqüência, de nossos profissionais.

O presente número é o primeiro a trazer um artigo de uma seção que se fixará na revista: Relato de Caso do Board Brasileiro de Ortodontia. Os diretores do Board, após a Fase II do exame $e^{2}$, selecionarão os casos que serão publicados nessa seção. Sugiro a todos a leitura desse artigo. Recomendo que façam a prova do $\mathrm{BBO}$ * $^{*}$

Boa leitura,

Jorge Faber - Editor Chefe

faber@dentalpress.com.br

* Dr. Jorge Faber mantém clínica privada de Ortodontia em Brasília/DF, se submeteu à Fase I do exame e se prepara para a Fase II.

\section{REFERÊNCIAS}

1. NETTA, B. C.; HUANG, J. G. Long-term posttreatment changes measured by the American Board of Orthodontics - objective grading system. Am. J. Orthod. Dentofacial Orthop., St. Louis, v. 127 , no. 4 , p. $444-450,2005$.

2. BOARD BRASILEIRO DE ORTODONTIA E ORTOPEDIA FACIAL. Exame de Certificação 2009. Disponível em: <http://www.bbo. org.br/>. Acesso em: 01 dez. 2008 